\title{
Research on the Teaching of Western Economics in Chinese University Classroom
}

\author{
Jiang Qiang ${ }^{1}$ \\ ${ }^{1}$ Economic School of Shandong Technology and Business University, Jiang Qiang, Yantai, Shandong Province, China \\ struggleqiang@163.com
}

\begin{abstract}
Under the background of globalization, science knows no boundaries. In particular, the development of natural science has fully benefited the economy and society of various regions. However, humanities and social sciences often have different local value judgments in different countries. Western economics was born during the British Industrial Revolution but its inherent logical system and theoretical arrangement can still guide the development of socialist market economy well. Yet, some of its academic hypotheses deviate from the socialist value judgment. How to teacher western humanities and social sciences in Chinese classrooms is not only a challenge, but also a manifestation of the art of lectures. It is necessary to clarify the theoretical logic, while adhering to the value judgment of one's own national culture, and help college students stick to cognitive and value orientation.
\end{abstract}

Keywords: Western economics, Chinese classroom, teaching research

\section{INTRODUCTION}

The world is colorful because of the prosperity of different cultures, and different regional cultures breed different logic of science. Science is originally used to guide practice. Different logic of science bred in cultural soils of different regions have promoted the economic and social development. Therefore, with open eyes, science knows no boundaries, and we should not talk about science and technology from the perspective ideology. However, science has different categories and can be divided into natural science and humanities and social science. Although natural science is generated in different regional cultures, its natural attributes remain basically unchanged, which is mainly to reveal the physical characteristics and laws of nature (Zhang Wenting, Yu Haibo, 2021). However, there are great differences in the objectivity of logical composition between humanities and social sciences and natural sciences. The real purpose of humanities and social sciences serves the management and operation of the society, involving knowledge compositions of different cultural backgrounds. Under the background of globalization, the world economy is moving towards integration. Economic globalization leads to the gradual expansion of logistics, business flow, trade flow and people flow around the globe. The transnational flow of human capital also leads to the effect of technology spillover and diffusion of knowledge and culture in different regions. Taking China's great achievements since the reform and opening up as an example, in the process of reform and opening up, approaches of attracting foreign investment, and import-export trade, and even "market for technology" have led to the spillover and diffusion of proven technologies in foreign countries. However, knowledge of humanities and social sciences in capitalist world has also been fully integrated into China's socialist market economy, which has caused some erosion of Chinese traditional culture (Li Hong'en, Jin Yule, 2012). Moreover, some beneficial disciplines in humanities and social sciences have also been introduced into China's higher education from the discipline system of western universities, mainly hoping to absorb the beneficial elements of disciplines and promote economic and social development. But some discipline systems deviate from China's traditional culture to a certain extent. Let's take western economics as an example. Western economics was born during the British Industrial Revolution. The Wealth of Nations written by Adam Smith was the prototype of microeconomics in western economics. However, the analytical framework of microeconomics is mainly based on the hypothesis of rational man, which deviates from the future ideals of socialism and communism (Xu Shang, 2007). It needs to be carefully studied how to deal with the deviation of different humanities and social sciences in the teaching process, and even its impact on teaching quality. This paper will take the teaching of western economics in Chinese universities 
as a case study, hope to clarify how to better realize the integration of eastern and western cultures under the background of globalization, and better maintain the cultural independence of different ethnic groups in the process of promoting the prosperity of world culture.

\section{THE CONTENT THAT DOES NOT ACCORD WITH CHINESE CULTURE IN THE TEACHING OF WESTERN ECONOMICS}

Western economics was born during the period of industrial revolution of capitalism, and got continuous improvement and development after various economic crises and financial evolution. Being the practice of guiding economic growth from macro-economic and micro perspective, it has been proved to be the most efficient economic theory at present. Subsequent derivative disciplines such as international economics, science of finance and science of investment are all developed on the basis of western economics. Western economics is a discipline that integrates natural science with social science. In particular, its inherent hypothesis of disciplines basically belongs to the category of humanities and social sciences. Specifically, the hypothesis that human is selfish in nature and the research on monopoly capital, state capitalism, efficiency and equality are all based on the value judgment of European and American regions, and some of them do not accord with Chinese culture. They are reflected in the following aspects.

\subsection{Western economics pays more attention to efficiency and ignores social equality}

Microeconomics is a science that aims to realize the optimal allocation of resources and pays more attention to efficiency. Developed countries in the west have experienced hundreds of years of development under its guidance, and have gone through the development process from agricultural society to industrial society and then to modernization. Efficiency has always been the focus of western economics. Although the total economic output has achieved major breakthroughs, the polarization between the rich and the poor in western society is still a very serious problem. Less than $1 \%$ of the population in the United States is in possession of $70 \%$ of the country's total wealth. Such social inequality has caused serious class differentiation and social division, thus laying great hidden dangers for the future political crisis. The fiscal policy and monetary policy of macroeconomics put more emphasis on the macro allocation of resources. From the micro perspective, it doesn't care whether all the holders of elements are almost from a few wealthy classes. In particular, the control of monetary policy by modern monetary theory has made western monetary policy move towards the era of negative interest rates. Such monetary release of quantitative easing has pushed up asset prices, which in turn has led to further polarization of wealth between the rich and the poor, showing more obvious Matthew effect. Socialism not only develops the economy but also pays more attention to social equality. China's huge project of "poverty alleviation" shows that the fourth-generation leader group centered by General Secretary Xi Jinping has paid more attention to the life of the poor of the underclass in the process of developing the overall economy. Although the expenditure on social equality goes against the efficiency theory of western economics, it eliminates social conflicts and lays a solid foundation for long-term sustainable economic growth (Wang Yuxia, Tang Wenbo, 2019).

\subsection{The value judgment of monopoly of state-owned enterprises in western economics has disregarded the public attribute of state-owned enterprises}

State-owned enterprise symbolizes the direction of socialism because it marks the public characteristics of socialism. Objectively speaking, state-owned enterprises are not advocated in the theoretical system of western economics, because compared with private enterprises, state-owned enterprises are prone to principal-agent problems, moral hazards, and adverse selection problems. Moreover, the management mechanism of state-owned enterprises hardly matches the market-oriented competition. Therefore, in the discipline framework of western economics, the development of state-owned enterprises is not advocated. Besides, the separate explanation of monopoly efficiency loss in microeconomics makes the development of state-owned enterprises subject to theoretical restrictions. But in western economics, the fiscal policy and monetary policy of macroeconomics need the support of state-owned enterprises. Particularly, state-owned enterprises will provide financial support for fiscal policy to buffer the debt ratio of local governments, and direct the monetary transmission of the country. Loans by state-owned enterprises are endorsed by the government, and such loans are more efficient when the economy suffers a huge impact, which will prevent the systemic risks of the macro economy and control macroeconomic fluctuations (Zhang Xu, Wang Tianjiao, 2020). In addition, Western economics attaches great importance to the study of employment. Relying solely on the development of market economy may easily lead to problems of spontaneity, blindness and delay. It is difficult for some unemployed people to find a job in the market, resulting in the problem of unemployment. Moreover, private enterprises attach more importance to efficiency and can hardly attract some unemployed people from the perspective of social equality. However, 
state-owned enterprises are different, because they ensure stable social employment and constitute the middle class, laying a solid foundation for maintaining economic growth and social stability.

\subsection{The hypothesis of rational man in microeconomics is inconsistent with China's reality during the outbreak of COVID-19 pandemic}

The research hypothesis of microeconomics is the hypothesis of rational man which is however not completely true in socialist countries. Socialist countries have the advantage of concentrating superior forces to accomplish large undertaking. Although capitalist society can realize the construction of large-scale infrastructure by relying on investment and financing in capital market, in social management, the logic system of western economics is hardly be brought into full use, and that of political economics can play its role instead. Taking COVID-19 pandemic, the largest external impact on the world in 2020, as an example, we will analyze the inconsistency between hypothesis of rational man in microeconomics and China's situation under the impact of pandemic. In the process of preventing and controlling the pandemic in China, many medical workers have been sacrificed, and a large number of researchers, experts and scholars have focused on China's fight against the pandemic, making self-sacrifice and preserving the lives and property of the country and the people, which is inconsistent with the hypothesis of rational man of microeconomics. This further urges us to reflect on the applicable conditions of microeconomics in China. We cannot completely deny western economics, because Its idea of market economy still fascinates us and gradually develops into a socialist market economic system with Chinese characteristics. However, some theoretical systems in it that do not accord with Chinese cultural characteristics need to be revised on the basis of China's practice for development

\section{HOW TO RESPOND TO CULTURAL CONFLICTS IN THE TEACHING OF DISCIPLINE KNOWLEDGE?}

College and university teachers as an important foundation for highly qualified talents cultivation and source of human capital, play an important role in guiding the ideological and logical development of human capital. However, colleges and universities are still places to pursue truth. We need an open mind to establish an attitude of "the sea refuses no river". At the same time, we need to follow scientific objectivity in studying conflicts between different cultures, handle conflicts between different cultures well, and insist on their own cultural independence. In view of the cultural conflicts in the teaching process of western economics in Chinese universities, I think we can initiate optimization from the following two aspects.

\subsection{Be inclusive and clarify the logic of different cultures}

First of all, the cultural development of the western world and China will be clearly clarified so that students can fully understand the development process of western economics. For the theory of state-owned enterprises in western economics, we should first make introduction in the logic of giving priority to efficiency, so that students can understand the disadvantages of state-owned enterprises and the problems in the development process based on this pattern. Then, in light of the previous economic crises in the western world, we should systematically instruct the powerful role state-owned enterprises play in handling macroeconomic fluctuations and maintaining macroeconomic stability. In particular, we should highlight the role of state-owned enterprises in sticking to social responsibilities and maintaining price stability and employment stabilization.

\subsection{Firmly adhere to value judgment of one's own culture and maintain cultural independence}

Although western economics was suddenly derived and developed based on the capitalist industrial revolution, it has significant scientific meaning and plays a crucial role in guiding the real economy, which deserves our careful study and is expected to be applied to the practice of national economic development. Therefore, we should look at the discipline system of western economics objectively. However, we should still stick to our own cultural value judgment, critically learn the beneficial elements of western economics while considering national cultural characteristics, and maintain cultural independence. For socialist countries, some contents of western economics that are too market-oriented and concerning laissez-faire capitalism should be treated critically, and especially should be based on the actual situation of China's economic and social development. For the beneficial elements of western economics, we should objectively describe the knowledge part of the laws of economic and social development with no value judgment. We should study hard and let students have full recognition and consideration in class. We must root the theory and discipline system of western economics in the classrooms of Chinese universities, and teach the contents selectively and inclusively, so as to form the value system standard of university teaching and realize cultural independence. 


\section{CONCLUSIONS}

Taking the problems of western economics in classroom teaching in Chinese universities as an example, this paper explores the influence of discipline systems bred under different backgrounds of humanities and social sciences on teaching practice. Western economics originated from the British Industrial Revolution at first, and gradually evolved with the development of previous economic crises and macro-control in the West, shaping modern western economics theories. However, there are some contents in the teaching of western economics that do not accord with Chinese culture, which are mainly manifested in the following three aspects: western economics pays more attention to efficiency and ignores social equality; the value judgment of monopoly of state-owned enterprises in western economics disregards the public attribute of state-owned enterprises; the hypothesis of rational man of microeconomics is inconsistent with China's reality during the outbreak of COVID-19 pandemic. Based on the analysis of the above facts, we put forward two suggestions for university teachers to impart knowledge of different cultural backgrounds: to be inclusive and explain the logic of different cultures clearly; to firmly stick to the value judgment of one's own culture and maintain cultural independence.

\section{REFERENCES}

[1] Zhang Wenting, Yu Haibo. Teaching Thinking: Attribute Characteristics, Structural Relationship and Operational Mechanism. Hunan Social Sciences. No.2, 2021.

[2] Li Hong'en, Jin Yule. Localization of Western Teaching Ideas: Significance, Approaches and Strategies. Educational Research and Experiment. No.2, 2012.

[3] Xu Shang. Dogmatism in Western Economics-An Investigation from the Perspective of Discipline System. Tianjin Social Sciences. No.1, 2007.

[4] Wang Yuxia, Tang Wenbo. Modern Economics Interpretation of Targeted Poverty Alleviation. Research on Financial and Economic Issues. No.7, 2019.

[5] Zhang $\mathrm{Xu}$, Wang Tianjiao. The Formation, Development and Transcendence of the Socialist State-Owned Enterprise Management System with Chinese Characteristics. Economic Review Journal. No.12, 2020. 